\title{
REFORMASI HUKUM PENYELESAIAN PERSELISIHAN HUBUNGAN INDUSTRIAL SECARA MEDIASI*
}

\author{
Yetniwati, Hartati, dan Meriyarni \\ Dosen Fakultas Hukum Universitas Jambi \\ E-mail: yetniwatisamad@yahoo.co.id
}

\begin{abstract}
Dispute settlement of Industrial Relations through mediation stipulated in article 8 of the Act Number 2 Year 2004 was assisted by a mediator of manpower officials. In addition, article 9 regulates the qualifications of mediator. These two articles are very discriminatory as they are contrary to the fact that mediator of government officer should also be subject to the Civil Service Act. Besides, the government mediator would have superiors and subordinates according to the hierarchy of their positions. This would open possibility of intervention of the superiors that would interfere the mediator in performing his/her duties. Consequently, independent mediator would never be reali-zed. In fact, mediator is not only from government officer but also from other field such as lawyers, lecturers, National Commission of Human Rights (Komnas HAM), and any capable and non-allign-ed mediators. This would be one of solutions for the government to solve the shortage of mediators in Indonesia.
\end{abstract}

Key words: mediation, mediator, law reform

\begin{abstract}
Abstrak
Penyelesaian Perselisihan Hubungan Industrial melalui mediasi yang diatur dalam Pasal 8 UU No.2 Tahun 2004 adalah penyelesaian yang dibantu oleh seorang mediator yang berasal dari pegawai dibidang ketenagakerjaan. Kemudian Pasal 9, mengatur syarat-syarat menjadi mediator. Kedua pasal ini sangat diskriminatif. Mediator seorang Pegawai Negeri Sipil (PNS) yang harus tunduk juga kepada Undang-undang Kepegawaian. Mediator sebagai seorang pegawai negeri sipil tentu mempunyai atasan maupun bawahan sesuai hierarkhi jabatannya, hal ini tidak menutup kemunkinan adanya intervensi dari atasan, sehingga akan mengganggu mediator dalam melaksanakan tugasnya, dan independent mediator tidak terwujud. Orang yang akan menjadi mediator dapat saja diperluas selain Pegawai Negeri Sipil dibidang ketenagakerjaan, diantaranya advokat, dosen, komnas HAM, mediator lain yang dianggap mampu dan netral. Hal ini juga merupakan salah satu solusi bagi pemerintah untuk mengatasi kekurangan mediator di Indonesia.
\end{abstract}

Kata kunci: mediasi, mediator, reformasi hukum

\section{Pendahuluan}

Manusia sebagai mahkluk sosial (zoon politicon) mempunyai kebutuhan yang beraneka ragam, yang diantaranya adalah sandang, papan, pangan. Demi terpenuhi semua kebutuhan itu manusia perlu bekerja, agar mendapatkan penghasilan. ${ }^{1}$ Dalam hal ini hak untuk bekerja

- Dibiayai oleh DIPA Universitas Jambi Tahun 2012 Nomor 0682/023-04.2.01/05/2012 tanggal 9 Desember 2011. Sesuai de-ngan Surat Perjanjian Pelaksanaan Penelitian Unggulan Perguruan Tinggi (UPT) Nomor: 24/UN.21.6/ PL/2012. Tanggal 15 Februari 2012.

1 Siti Kunarti, "Perjanjian Pemborongan Pekerjaan (Outsorcing) dalam Hukum Ketenagakerjaan", Jurnal Dina- secara implisit diatur dalam Pasal 27 ayat 2 UUD 1945 yang mengatur bahwa tiap-tiap warga negara berhak atas pekerjaan dan penghidupan yang layak. Pencapai kehidupan yang layak dalam hubungan kerja tersebut tidak begitu mudah diperoleh, banyak permasalahan yang dialami antara pekerja dengan pihak pengusaha ditemukan dalam hubungan kerja.

Bervariasinya permasalahan yang menimbulkan konflik, tentunya tidak selalu dapat diselesaikan dalam waktu yang sesingkat-singkatnya

mika Hukum, Vol.9 No.1, Januari 2009, Purwokerto: FH Unsoed, hlm. 67. 
dengan hasil dari pemecahan masalah yang dapat diterima bagi para pihak yang berselisih, bahkan tidak jarang berujung pada munculnya sengketa. ${ }^{2}$ Perselisihan antara pekerja dengan pengusaha tidak dapat diselesaikan dengan pemutusan hubungan kerja atau pengunduran diri saja, hal ini dapat berakibat memperburuk kondisi hubungan pekerja dengan pengusaha. ${ }^{3} \mathrm{Be}$ berapa literatur menyebutkan, bahwa faktorfaktor pendorong terjadinya konflik adalah karena perbedaan pendapat dan pandangan, perbedaan tujuan, ketidak sesuaian cara pencapaian tujuan, pengaruh negatif dari pihak lain, per-saingan, ${ }^{4}$ adanya keinginan dari salah satu pihak untuk menyampaikan keinginannya secara ber-lebihan, kurangnya pemahaman terhadap suatu peraturan perundang-undangan. ${ }^{5}$

Penyelesaian perselisihan hubungan serikat pekerja dengan pengusaha yang dulu atur dalam UU No. 22 Tahun 1957 dikenal dengan istilah penyelesaian perselisihan perburuhan, sekarang menurut UU No. 2 Tahun 2004 dikenal dengan Penyelesaian Perselisihan Hubungan Industrial. Proses penyelesaian menurut UU No. 2 Tahun 2004 diawali dengan penyelesaian di luar pengadilan penyelesai-an senketa di luar pengadilan menghasilkan kesepakatan maka dibuatlah surat perjanjian bersama dan jika tidak menghasilkan kesepakatan, maka proses selanjutnya diteruskan ke pengadilan hubungan industrial.

Perselisihan Hubungan Industrial menurut UU No. 2 Tahun 2004 terlihat ada 4 jenis perse-

Riska Fitriyani, Proses Mediasi di Kabupaten Siak, Jurnal Ilmu Hukum, Vol. 3 No.1, Tahun 2013, Pekanbaru: FH Universitas Riau, tersedia di website: ejournal.unri.ac. $\mathrm{id} /$ index. php/JIH/article/.../1024, diakses tanggal 9-22014

3 Mila Karmila Adi, "Masa Depan Arbitrase Sebagai Mekanisme Penyelesaian Perselisihan Hubungan Industrial di Indonesia", Jurnal Hukum FULTEX, Vol. 17 No. 2, April 2010, hlm.295, Fakultas Hukum Universitas Islam Indonesia, hlm. 295.

4 Dahlia dan Agatha Jumiati, "Penyelesaian Perselisihan Hubungan Industrial Berdasarkan Undang-undang Nomor 2 Tahun 2004", Jurnal Wacana Hukum, Vol. IX No.2, Ok tober Tahun 2011, Surakarta: Fakultas Hukum Unisri, hlm. 39.

5 Frendy Sinaga, “Tinjauan Yuridis Terhadap Anjuran Yang Dikeluarkan Mediator Hubungan Industrial Di Dinas Tenaga Kerja Dan Transmigrasi Provinsi Kalimantan Timur", Jurnal Beraja Niti, Vol. 2 no.12 Tahun 2013, Fakultas Hukum Universitas Mulawarman. Tersedia di website: http://e-journal.fhunmul.ac.id/index.php/beraja/article/view/142 diakses 12-2-2014. lisihan, yaitu: perselisihan hak, perselisihan kepentingan, perselisihan pemutusan hubungan kerja (PHK), perselisihan antar serikat pekerja/ serikat buruh dalam perusahaan. Penyelesaian perselisihan ini dapat dilakukan melalui: negósiasi, mediasi, konsiliasi, arbitrase, pengadilan perselisihan hubungan industrial dan Mahkamah Agung. Masing-masing lembaga penyelesaian akan menyelesaikan sengketa sesuai dengan jenis perselisihan yang diatur dalam perundangundangan ini.

Penyelesaian perselisihan secara mediasi merupakan penyelesaian perselisihan yang dilakukan dengan bantuan mediator yang berada di setiap kantor instansi yang bertanggung jawab dibidang ketenagakerjaan kabupaten/kota ( $\mathrm{Pa}$ sal 8 UU No. 2 Tahun 2004). Mediator merupakan pihak ketiga sebagai pihak penengah yang harus bersifat netral dalam menyelesaikan perselisihan. Ketentuan Pasal 9 UU No. 2 Tahun 2004 mengatur syarat-syarat menjadi mediator, yakni beriman dan bertaqwa kepada Tuhan Yang Maha Esa; warga negara Indonesia, berbadan sehat; menguasai peraturan ketenagakerjaan; berwibawa, jujur, adil dan berkelakuan tidak tercela; berpendidikan sekurang-kurangnya strata satu (S1); memiliki legitimasi dari menteri tenaga kerja dan transmigrasi. Berarti disini mediator seorang pegawai negeri sipil (PNS) yang harus tunduk juga kepada Undang-undang Kepegawaian.

Mediasi sebagai salah satu parnata penyelesaian senketa bisnis mulai dikenal di Indonesia sejak tahun 1990-an, mediasi mempunyai karakteristik yang khas, yaitu mempunyai jalan kompromi dengan melibatkan pihak ketiga yang disebut mediator. ${ }^{6}$ Mediator sebagai seorang pegawai negeri sipil tentu mempunyai atasan maupun bawahan, tidak menutup kemungkinan adanya intervensi dari atasan. UU No. 2 Tahun 2004 yang mengatur tentang mediator kelihatannya kabur, diskriminatif, karena tidak ada ketentuan yang memperbolehkan mediator lain selain dari PNS dibidang ketenagakerjaan.

6 Bambang Heri Supriyanto, "Mediasi Sebagai Salah Satu Penyelesaian Senketa Bisnis Di Pusat Mediasi Nasional", Jurnal Reformasi Hukum, Vol. XIV NO.1 Januari -Juni 2010, Jakarta: Universitas Islam Jakarta. 
Ketentuan mediasi dalam UU No. 2 Tahun 2004 kelihatannya kabur, karena tidak ada ketentuan yang memperbolehkan mediator lain selain dari PNS dibidang ketenagakerjaan. Penyelesaian perselisihan hubungan industrial tidak terlalu signifikan perbedaannya dengan perselisihan perdata pada umumnya. Penyelesaian perselisihan hubungan industrial secara litigasi berpedoman kepada ketentuan Hukum Acara Perdata yang berlaku dalam peradilan umum (Pasal 57). Mediator pada peradilan perdata secara umum dapat dilakukan oleh siapa saja, sepanjang dia mampu sebagai pihak penengah yang netral dan dipercaya oleh para pihak yang bersengketa.

Mediator sebagai pihak penengah dalam alternatif penyelesaian sengketa terdiri atas 3 (tiga) tipologi, sebagaimana yang dikemukakan oleh Christopher W.Moore. ${ }^{7}$ Pertama, social net-work mediators, mediator berperan dalam se-buah sengketa atas dasar adanya hubungan so-sial antara mediator dengan para pihak yang bersengketa, misalnya: tokoh agama, tokoh masyarakat.

Kedua, authoritative mediators, yaitu mereka yang berusaha membantu pihak yang bersengketa untuk menyelesaikan perbedaan dan memiliki posisi yang kuat sehingga mereka memiliki potensi atau kapasitas untuk mempegaruhi hasil akhir dari sebuah proses mediasi, akan tetapi mediator tipe ini selama menjalankan perannya tidak menggunakan kewe-nangan atau pengaruhnya, hal ini didasarkan keyakinan atau pandangan bahwa pemecahan masalah terbaik untuk sebuah kasus bukanlah ditentukan oleh dirinya selaku pihak yang perpengaruh, melainkan dihasilkan oleh upaya pihak yang bersengketa sendiri.

Ketiga, indenpendent mediators. Mediator dapat menjaga jarak antar pihak manapun dengan persoalan yang dihadapi, mediator tipe ini lebih banyak ditemukan dalam masyarakat, budaya yang mengembangkan tradisi kemandirian akan menghasilan mediator yang profesional, model mediator ini mulai dipraktekan dan

Suyud Margono, 2004, Alternative Dispute Resolution dan Arbitrase, Proses Pelembagaan dan Aspek Hukum, Bogor: Ghalia Indonesia, hlm. 62. berkembang di Amerika Utara, keadaan seperti ini dapat dilihat dan dibuktikan dengan lahir, dan berkembangnya profesi mediator seperti pengacara, dokter, akuntan dan sebagainya.

Ketiga tipe meditor tersebut dapat dikatakan bahwa meditor yang ditetapkan oleh UU No. 2 Tahun 2004 termasuk tipe authoritative mediators, yaitu pihak penengah dari instansi pemerintah yang kekuasaannya ditetapkan oleh undang-undang, apakah ketiga tipe ini dapat menjadi mediator?, maka disini tim peneliti akan meneliti dan menelaah lebih lanjut, agar adanya reformasi hukum penyelesaian perselisihan hubungan industrial secara mediasi.

Bergulirnya reformasi disegala aspek, sebagai bentuk pembaharuan akibat dari permasalahan dan kelemahan berbagai aspek kehidupan di zaman sebelumnya. Hukum ketenagkerjaan di zaman reformasi sudah melakukan pembaharuan undang-undang yaitu: UU No. 21 tahun 2000 tentang Serikat Pekerja/Serikat Buruh, UU No. 13 Tahun 2003 tentang Ketenagakerjaan, UU No. 2 Tahun 2004 tentang Penyelesaian Perselisihan Hubungan Industrial. Ketiga undangundang tersebut telah membawa dampak terhadap dinamika masyarakat pekerja dan pengusaha, serta peran pemerintah sebagai penegak hukum dan pengayom masyarakat, namun substansi peraturan tersebut masih banyak mendapatkan kritikan dari berbagai masyarakat.

Menurut Asri Wijayanti, pada masa pasca reformasi seharusnya kondisi ketenagakerjaan menjadi lebih baik, tetapi sangat disayangkan, kenyataan pemerintah kurang berpihak pada pekerja, terutama pekerja unskilllabour ${ }^{8}$. Kebijakan ekonomi nasional lebih mementingkan sistem pertumbuhan ekonomi dengan investasi, sehingga menekan pekerja. Dengan kata lain, keadaan seperti ini harus dipikirkan lebih jauh lagi.

\section{Permasalahan}

Berangkat dari permasalahan hukum tentang mediator dalam penyelesaian perselisihan hubungan industrial, maka disini peneliti mem-

8 Asri Wijayanti. 2009, Hukum Ketenagakerjaan Pasca Reformasi, Jakarta: Sinar Grafika, hlm. 35. 
bahas mengenai: pertama, Pengaturan penyelesaian perselisihan hubungan industrial secara mediasi dalam perspektif UU No. 2 Tahun 2004; dan kedua, Konsep pengaturan mediasi yang ideal untuk menyelesaikan perselisihan hubungan industrial dengan adil dan objektif.

\section{Metode Penelitian}

Tipe penelitian yuridis normatif, dengan pendekatan konseptual (conceptual approach), pendekatan perundang-undangan (normative approach) dan sinkronisasi hukum. Bahan hukum primer terdiri dari: Undang-undang dasar tahun 1945 yang diamandemen, UU No. 2 Tahun 2004 tentang Penyelesaian Perselisihan Hubungan Industrial, UU No. 14 Tahun 2005 tentang Guru dan Dosen, UU No. 18 Tahun 2003 Tentang Advokat, UU No. 39 Tahun 1999 tentang Hak Asasi Manusia, Peraturan Mahka-mah Agung No. 01 Tahun 2008 Tentang Mediasi di Pengadilan, Peraturan dan Keputusan Menteri Tenaga Kerja dan Transmigrasi (Kepmenakertrans) No. Kep: 92/ Men/VI/2004 tentang Peng-angkatan dan Pemberhentian Mediator serta Tata Kerja Mediasi. Bahan hukum sekunder terdiri dari buku-buku, jurnal dan makalah hukum yang relevan dengan judul, bahan hukum tertier yaitu kamus hukum. Data yang ditemukan, kemudian diinterprestasikan, dievaluasi dan secara deduktif ditarik kesimpulan. Hasil penelitian ini diharapkan bisa menjadi bahan masukan dalam perubahan atau revisi UU No. 2 Tahun 2004.

\section{Pembahasan}

Pengaturan Penyelesaian Perselisihan Hubungan Industrial secara Mediasi dalam Perspektif UU No. 2 Tahun 2004 Tentang Pengadilan Hubungan Industrial

Penyelesaian kasus-kasus perselisihan hubungan industrial merupakan masalah yang sangat penting dalam hubungan industrial. Hubungan industrial yang harmonis akan menciptakan ketenangan bekerja, yang akan berpengaruh pula pada peningkatan produktifitas dan kesejahteraan pekeja. ${ }^{9}$ Analisis tentang pengatur-

Diana Putong, 2012, "Penyelesaian Perselisihan Tenaga Kerja Kasus Adam Air Melalui Mediasi Pada Tahap Perundingan Tripartit Berdasarkan Undang-udang No.2 Tahun an penyelesaian perselisihan hubungan industrial secara mediasi menurut UU No. 2 Tahun 2004 dapat diuraikan dari aspek beberapa aspek, yaitu: aspek kelembagaan, dan aspek prosedur penyelesaian.

Berkaitan dengan aspek pengaturan mediasi dari aspek kelembagaan yang berwenang menyelesaian perselisihan hubungan industrial dapat dijelaskan sebagai berikut. Penyelesaian perselisihan hubungan industrial secara mediasi merupakan lanjutan dari kegagalan penyelesaian secara bipartit, dan para pihak tidak memilih lembaga konsiliasi atau arbitrase untuk menyelesaikan perselisihan mereka, maka para pihak akan menyelesaikan perselisihan melalui mediasi. Penyelesaian secara mediasi hubungan industrial sebagaimana diatur dalam Pasal 1 Butir 11 UU No. 2 Tahun 2004 yaitu penyelesaian perselisihan hak, perselisihan kepentingan, perselisihan pemutusan hubungan kerja dan perselisihan antar serikat pekerja/serikat buruh hanya dalam satu perusahaan, melalui musyawarah yang ditengahi oleh seorang atau lebih mediator yang netral. Artinya semua jenis perselisihan dapat diselesaikan melalui mediasi.

Mediator sebagaimana ketentuan Pasal 9 UU No. 2 Tahun 2004 harus memenuhi beberapa persyaratan, namun jika diperhatikan Pasal 9 UU No. 2 Tahun 2004 belum mengatur secara rinci syarat untuk dapat diangkat menjadi mediator dalam penyelesaian hubungan industrial. Hal itu dapat dimaklumi jika memperhatikan ke-tentuan Pasal 9 huruf $\mathrm{g}$ yaitu syarat-syarat lain yang ditetapkan oleh menteri, selain itu, Pasal 16 UU No. 2 Tahun 2004 juga mengamanatkan bahwa ketentuan mengenai tata cara pengangkatan dan pemberhentian mediator, serta tata kerja mediasi diatur dengan Keputusan Menteri. Sebagai aturan pelaksana Pasal 9 huruf g dan Pasal 16 UU No. 2 Tahun 2004, maka dikeluarkan Keputusan Menteri Tenaga Kerja No. Kep/ 92/VI/2004 tentang Pengangkatan dan Pemberhentian Mediator serta Tata Kerja Mediasi (selanjutnya disebut Kepmenaker No. Kep/

2004", Jurnal Arika, Vol. 06. No. 1. Februari 2012, Tersedia di website: http://www.paparisa.unpati.ac.id/paperrepo/ppr-iteminfo_ink.php?id=243. Diakses $25 \mathrm{Ma}$-ret 2012 
92/VI/2004). Pasal 3 Kepmenaker No. Kep/92/ $\mathrm{Vl} / 2004$, menentukan syarat-syarat seseorang untuk menjadi mediator yaitu:

1) Pegawai Negeri Sipil pada instansi/dinas yang bertanggung jawab di bidang ketenagakerjaan;

2) Beriman dan bertaqwa kepada Tuhan Yang Maha Esa;

3) Warga negara Indonesia;

4) Berbadan sehat menurut surat keterangan dokter;

5) Menguasai peraturan perundangan di bidang ketenagakerjaan;

6) Berwibawa, jujur, adil, dan berkelakuan tidak tercela;

7) Berpendidikan sekurang-kurangnya Strata Satu (S1); dan

8) Memiliki legitimasi dari Menteri Tenaga Kerja dan Transmigrasi.

Ketentuan Pasal 4 Kepmenaker No. Kep/ 92/VI/2004 mengatur tata cara untuk memperoleh legitimasi mediator sebagai berikut:

a) Calon mediator pada Departemen Tenaga Kerja dan Transmigrasi diusulkan oleh Direktur Jenderal Pembinaan Hubungan Industrial;

b) Calon mediator pada instansi yang bertanggung jawab di bidang ketenegakerjaan Provinsi diusulkan oleh Gubernur;

c) Calon mediator pada instansi yang bertanggung jawab di bidang ketenegaker-jaan Kabupaten/Kota diusulkan oleh Bupati/ Walikota.

Ketentuan mediator tersebut di atas dapat dipahami, bahwa secara kelembagaan yang berwenang menyelesaikan perselisihan hubungan industrial melalui mediasi hanya mediator yang berasal dari PNS di instansi pemerintah yang bertanggung jawab dibidang ketenagakerjaan. Artinya tidak ada mediator lain selain PNS yang telah mendapat sertifikasi mediator dari Menteri Tenagakerja. Semua peraturan ini akan berakibat:

Pertama, adanya peluang tidak netralnya mediator PNS sebagaimana yang diatur dalam Pasal 8 UUNo.2 Tahun 2004, mediator PNS Disnaker yang tentu mempunyai hirarkhi jabatan, apabila ada oknum pejabat diatasnya, mengintervensi dirinya agar dapat berpihak ke salah satu pihak yang berselisih, apalagi pejabat yang mengintervensi itu adalah pejabat mengusulkannya dia menjadi mediator, tentu akan berakibat mediator PNS tidak nyaman dalam melaksanakan tugasnya, dan Ketentuan Pasal 1 (11) UU No. 2 Tahun 2004 yang mengatur: “... mediasi hubungan industrial melalui musyawarah yang ditengahi oleh seorang atau lebih mediator yang netral" itu sulit terlaksana. Kewenangan mediator sebagaimana diatur pada Ketentuan Pasal 9 Kepmenakertrans No. Kep-92/Men/VI/ 2004, adalah sebagai berikut:

a. Menganjurkan kepada para pihak yang berselisih untuk berunding terlebih dahulu dengan beritikad baik sebelum dilaksanakan mediasi.

b. Meminta keterangan, dokumen dan surat-surat yang berkaitan dengan perselisihan.

c. Mendatangkan saksi atau saksi ahli dalam mediasi apabila diperlukan.

d. Membuka buku dan meminta surat-surat yang diperlukan dari para pihak dari instansi atau lembaga terkait.

e. Menerima atau menolak wakil dari para pihak yang berselisih apabila ternyata tidak meiliki surat kuasa. Kewenangan ini akan terganggu apabila ada intervensi dari atasan berdasarkan hirarkhi jabatan.

Kedua, Ketentuan Pasal 8 UU No. 2 Tahun 2004 inkonsistensi dengan Pasal 27 ayat (2) UUD 1945 dan Pasal 28 ayat (2) UUD 1945, yang menganut prinsip persamaan hak, persyaratan untuk menjadi mediator yang diatur dalam $\mathrm{Pa}$ sal 8 dan Pasal 9 UU No. 2 Tahun 2004 bersifat diskriminatif, karena membedakan mediator dalam hubungan industrial hanya PNS dari dinas bidang ketenagakerjaan dengan mediator dalam penyelesaian perkara perdata umumnya. Ketiga, Mediator yang diatur dalam UU No. 2 Tahun 2004, merupakan salah satu perwujudan intervensi pemerintah dalam hubungan industrial". ${ }^{10}$

Berkaitan dengan aspek pengaturan mediasi dari aspek prosedur atau tahapan mediasi,

10 Lanny Ramli, Ratio PNS Sebagai Mediator Dalam Penyelesaian Perselisihan Hubungan Industrial. Jurnal Magister Hukum, Vol. 1 No. 2, Tahun 2010, Malang: Program Studi Magister Ilmu Hukum Universitas Wisnuwardhana, hlm. 298 
dapat dijelaskan sebagai berikut. Penyelesaian perselisihan melalui mediasi dilakukan oleh mediator yang berada di setiap kantor instansi yang bertanggung jawab di bidang ketenagakerjaan Kabupaten/Kota. Dalam waktu selambatlambatnya 7 (tujuh) hari kerja setelah menerima pelimpahan penyelesaian perselisihan mediator harus sudah mengadakan penelitian tentang duduknya perkara dan segera mengadakan sidang mediasi. Adapun mekanisme penyelesaian perselisihan hubungan industrial melalui mediasi dilaksanakan sebagai berikut. Pertama, Penyelesaian melalui mediasi dilaksanakan paling lama 30 (tiga puluh) hari kerja terhitung sejak menerima pelimpahan penyelesaian perselisihan. Kedua, bilamana ternyata dalam sidang mediasi tercapai kesepakatan, dibuat Perjanjian Bersama yang ditandatangani oleh para pihak, dengan disaksikan oleh mediator untuk kemudian didaftarkan di Pengadilan Hubungan Industrial pada Pengadilan Negeri di wilayah hukum pihak-pihak yang berselisih. Ketiga, Bila ternyata dalam mediasi tidak tercapai kesepakatan, mediator membuat anjuran tertulis. Keempat, Mediator harus sudah mengeluarkan anjuran tertulis selambat-lambatnya 10 (sepuluh) hari setelah sidang mediasi dilaksanakan.

Kelima, Pihak-pihak yang berselisih harus sudah menyampaikan tanggapan atau jawaban secara tertulis atas anjuran mediator selambatlambatnya 10 (sepuluh) hari setelah anjuran mediator diterima. Keenam, Apabila ternyata pihak-pihak yang berselisih tidak memberikan tanggapan atau jawaban tertulis, dianggap menolak anjuran mediator. Ketujuh, Dalam hal pihak-pihak yang berselisih dapat menerima anjuran mediator selambat-lambatnya 3 (tiga) hari harus dibuatkan perjanjian bersama untuk kemudian didaftarkan di pengadilan hubungan Industrial pada pengadilan negeri di wilayah domisili hukum pihak-pihak yang berselisih untuk mendapatkan akta bukti pendaftaran. Kedelapan, Dalam hal tidak tercapai kesepakatan dan atau pihak-pihak menolak anjuran mediator, salah satu pihak dapat melanjutkan penyelesaian perselisihan dengan mengajukan gugatan ke pengadilan hubungan industrial pada penga- dilan negeri di wilayah hukum pekerja/buruh bekerja.

Konsep Pengaturan Mediasi yang Ideal untuk Penyelesaian Perselisihan Hubungan Industrial yang Adil dan Objektif

Reformasi hukum penyelesaian perselisihan hubungan industrial, termasuk dalam kategori reformasi hukum ekonomi, karena para pihak yang bersenketa adalah pelaku usaha yang akan berperan dalam pembangunan ekonomi. Pengertian reformasi hukum ekonomi menurut Peter Mahmud Marzuki sebagaimana dikutib Asri Wijayanti, bahwa reformasi ekonomi mencakup tiga komponen yaitu: pertama, komponen pengembangan hukum yang kegiatannya memberikan sumbangan naskah akademik perundang-undangan baru atau perubahan perubahan undangundang dalam kegiatan ekonomi; kedua, sistem informasi hukum yang canggih; ketiga, pendidikan hukum yang mampu meningkatkan kemampuan sumber daya manusia di bidang hukum". ${ }^{11}$

Ketentuan Pasal 6 UU No. 12 Tahun 2011, menetapkan bahwa peraturan perundang-undangan itu harus berasaskan keadilan yang merata, artinya peraturan perun-dang-undangan itu harus mencerminkan keadilan bagi setiap warga negara tanpa kecualinya. Adil disini harus terdapat dalam hukum materil dan hukum formil atau dengan kata lain adil dalam proses penegakan hukumnya.

Satjipto Rahardjo sebagaimana dikutip oleh Rusli Muhammad mengatakan, bahwa pada hakekatnya hukum mengandung ide atau konsep-konsep dan dengan demikian boleh digolongkan kepada suatu yang abstrak, termasuk ide tentang keadilan, kepastian hukum dan kemanfaatan sosial. ${ }^{12}$ Seorang penegak hukum dapat menghasilkan putusan yang adil dan berkeadilan manakala aturan hukum yang akan di-

11 Asri Wijayanti, “Reformasi Hukum Dalam Penyelenggaraan Jamsostek Bagi Pekerja Swasta”, Yustitia, Vol. 1 No. 1, April 2007, Surabaya: UM Surabaya.

12 Rusli Muhammad, "Kemadirian Pengadilan Dalam Proses Penegakan Hukum Pidana Menuju Sistem Peradilan Yang Bebas Dan Bertanggung Jawab”, Jurnal Hukum, Vol. 16 No. 4, Oktober 2009, Yogyakarta: FH UII Yogyakarta, hlm. 470. 
tegakkan nyata-nyata tidak bertentangan dengan konsep keadilan, kecuali penegak hukum itu berani bertindak tidak hanya sekedar sebagai corong undang-undang. Seperangkat aturan hukum yang baik dan adil akan menghasilkan putusan yang adil dan berkeadilan, manakala dipegang oleh penegak hukum yang baik.

Berdasarkan konstruksi argumentasi di atas, maka yang maksud dengan "Pengaturan Mediasi yang ideal untuk Penyelesaian Perselisihan Hubungan Industrial yang adil dan objektif" adalah proses mediasi yang dapat memberikan jaminan anjuran dan/atau penyelesaian perselisihan hubungan industrial yang adil dan objektif. Kata "adil" dan "objektif" dalam kalimat "Pengaturan Mediasi yang ideal untuk Penyelesaian Perselisihan Hubungan Industrial yang adil dan objektif" merupakan kata yang saling bertalian satu sama lainnya. Putusan yang adil tidak akan tercipta, manakala dipegang oleh penegak hukum yang tidak objektif dalam memberikan penilaian dan pertimbangan hukum. Penegak hukum yang adil dan objektif tersebut dapat lahir oleh beberapa faktor yaitu: adanya aturan hukum yang adil dan objektif; tidak ada peluang intervensi dari berbagai pihak terhadap penegakan hukum; tidak diskriminasi dalam melakukan negosiasi atau musyawah; arif dan bijaksana mendengarkan argumen yang disampaikan pihak yang bersenketa; mempunyai pengetahuan yang cukup dalam bidang ketenagakerjaan atau objek perselisihan. Proses mediasi merupakan salah satu bentuk penegakan hukum, maka kelima faktor diatas juga akan verlaku pada proses mediasi dalam penyelesaian hubungan industrial.

Anjuran yang diberikan oleh mediator tidak menutup kemunkinan memberikan restorative justice. Restorative justice adalah peradilan yang menekankan perbaikan atas kerugian yang disebabkan atau terkait dengan tindak pidana. ${ }^{13}$ Artinya restorative justice dapat dilakukan oleh mediator sepanjang disetujui oleh para

13 Kuat Puji Prayitno, Restorative Justice Untuk Peradilan Di Indonesia (Perspektif Yuridis Filosofis Dalam Penegakan Hukum In Concreto), Jurnal Dinamika Hukum, Vol. 12 No. 3, September 2012, Purwokerto: FH Unsoed, hlm. 409. pihak yang berselisih, contohnya dalam penyelesaian perselisihan pemutusan hubungan kerja (PHK) yang disebabkan oleh pekerja yang lalai melakukan pekerjaan, sehingga merugikan perusahaan maka mediator melakukan penemuan hukum dalam menghitung kerugian perusahaan.

Konsep pengaturan mediasi yang ideal, penyelesaian yang adil dan objektif tentu akan diselesaikan oleh kelembagaan yang adil dan tidak diskriminasi, pihak yang bersenketa dapat memilih mediator di anggap para pihak netral mampu berbuat adil dan prosedur penyelesaian yang adil sebagaimana uraian selanjutnya.

\section{Aspek Kelembagaan Mediator yang Berwenang Menyelesaikan Perselisihan Hubungan Indus- trial}

Mediator sebagai pegawai negeri sipil tentu tidak lepas dari hierarki jabatan. Meskipun ia memangku jabatan fungsional, namun dari awal pencalonan mediator yang akan dilegitimasi oleh Menteri Tenaga Kerja. Hal ini akan berakibat adanya keterkaitan antara mediator dengan pejabat struktural, sehingga prinsip netralnya bisa terganggu dalam pelaksanaan tugas mediasi apabila ada intervensi dari pejabat struktural sebagai atasannya. Posisi PNS sebagai mediator dalam penyelesaian perselisihan hubungan industrial seperti ini merupakan perwujudan intervensi pemerintah dalam hubungan industrial, ${ }^{14}$ karena diragukannya prinsip netralnya seorang mediator.

Menurut ketentuan ini UU No. 2 Tahun 2004 serta Kepmenakertrans No. Kep.92/MEN/ $\mathrm{VI} / 2004$ menutup peluang bagi lembaga lain menjadi mediator untuk menyelesaikan perselisihan secara mediasi seperti pengacara, akademisi dan mediator tipe lain. Mediator yang diatur dalam UU No. 2 Tahun 2004 merupakan salah satu perwujudan intervensi pemerintah dalam hubungan industrial. ${ }^{15}$ Sementara masih banyak lembaga lain yang bisa dijadikan mediator

\footnotetext{
14 Lanny Ramli, Ratio Legis PNS Sebagai Mediator Dalam Penyelesaian Perselisihan Hubungan Industrial, Jurnal Magister Hukum Vol. 1 No. 2, Tahun 2010, Universitas Wisnuwardhana Malang, tersedia dalam website: http: // isjd.pdii.lipi.go.id/admin/jurnal/1210296338_2086_652 6.pdf

15 Lannny Ramli, log.cit.
} 
dalam penyelesaian perselisihan hubungan industrial seperti advokat, dosen, Komnas HAM dan sebagainya.

Ketentuan Pasal 3 huruf a dan huruf $\mathrm{g}$ Kepmenakertrans No. Kep/92/VI/2004, menghadapi berbagai persoalan yang pada pokoknya meliputi tiga hal: Pertama pengaturan yang meletakan hanya PNS sebagai mediator yang dapat mempengaruhi prinsip netralitas seorang mediator, karena besarnya kemungkinan timbulnya intervensi; Kedua terbatasnya jumlah mediator; Ketiga tingginya beban anggaran yang ditanggung APBN atau APBD. Keadaan di atas jika terus dipertahankan maka akan menimbulkan ketidakefektifnya mediator dan kurangnya kepercayaan masyarakat terhadap penyelesaian melalui mediasi, jika hal itu terjadi maka tujuan untuk mengurangi tunggakan perkara di pengadilan tidak akan terwujud.

Salah satu upaya yang dapat ditempuh untuk mengatasi persoalan ini adalah dengan jalan melakukan pembaharuan atau reformasi terhadap materi hukum UU No. 2 Tahun 2004, terutama ketentuan pasal yang langsung terkait dengan pengaturan tentang eksistensi tunggal PNS sebagai mediator dalam proses mediasi untuk menyelesaikan perselisihan hubungan Industrial. Penting diingat pokok reformasi tersebut haruslah bertujuan untuk mengarahkan terciptanya pengaturan mediasi yang dapat menjamin netralitas dan objektivitas mediator, dengan demikian diharapkan dapat menghasilkan anjuran dan keputusan hukum yang adil dan objektif.

Menurut peneliti salah satu bentuk reformasi yang penting dilakukan adalah merekonstruksi ulang konsep mediator. Saat ini mediator yang ditetapkan oleh UU No. 2 Tahun 2004 termasuk tipe Authoritative mediator. Berdasarkan pendapat Christopher W. Moore, maka ada dua alternatif tipologi mediator yaitu social networks mediators dan independent mediators. Kedua bentuk tipologi ini tentunya dapat dipertimbangkan satu persatu, sehingga dapat ditemukan tipologi dapat menyelesaikan persoalan bangsa kita. Oleh karena itu tipologi social network mediators menurut hemat peneliti kurang begitu tepat untuk dapat digunakan dalam penyelesaian perselisihan hubungan industrial yang membutuhkan orang-orang yang profesional di bidangnya.

Independent mediators memiliki keunggulan utama yakni mediator dapat menjaga jarak antar pihak manapun dengan persoalan yang dihadapi. Tradisi kemandirian yang mendasari atau membentuk Independent mediators akan menghasilkan mediator yang professional, artinya Independent mediators adalah orang yang benar-benar memahami bidang pekerjaannya dan tidak dapat dipengaruhi oleh siapapun. Bidang pekerjaan tersebut meliputi aspek yang sangat luas, misalnya: musisi, jurnalistik, arsitek, tenaga pengajar, akademisi dan praktisi. Dalam bidang ilmu hukum misalnya ada beberápa jenis tenaga profesional antara lain akademisi hukum seperti Dosen dan praktisi hukum antara lain Advokat dan Komnas HAM.

Berkaitan dengan reformasi/ rekonstruksi ulang konsep mediator dalam UU No. 2 Tahun 2004 perlu dipertimbangkan untuk memasukan independent mediators untuk mendampingi mediator yang berasal dari PNS di instansi pemerintah yang bertanggung jawab dibidang ketenagakerjaan. Pertanyaan selanjutnya Independent mediators bagaimana yang dapat menjadi mediator dalam penyelesaian perselisihan hubungan industrial? Menurut hemat penulis advokat, dosen, Komnas HAM dan profesi lain yang dianggap para pihak menguasai atau berpengalaman dalam pokok sengketa, dapat dipertimbangkan untuk menjadi mediator sebagai berikut.

Pertama, advokat sebagai mediator. Argumentasi yang dimungkinkan memperbolehkan advokat sebagai mediator dalam perselisihan hubungan industrial. Argumentasi pertama adalah bahwa berdasarkan hukum positif di Indonesia salah satunya UU No. 18 Ta-hun 2003 Tentang Advokat, Pada Pasal 1 ayat (1) UU No. 18 Tahun 2003 mengatur bahwa advokat adalah orang yang berprofesi memberikan jasa hukum, baik di dalam maupun di luar pengadilan yang memenuhi persyaratan berdasarkan ketentuan undang-undang ini. Pengertian jasa hukum adalah jasa yang diberikan oleh advokat berupa memberikan konsultasi hukum, bantuan hukum, menjalankan kuasa, mewakili, mendampingi, membela, dan melakukan tindakan hukum lain 
untuk kepentingan hukum klien (ayat (2)). Perbuatan mediator sebagai penengah dalam menyelesaikan sengketa merupakan salah satu perbuatan konsultasi hukum atau tindakan hukum lainnya untuk kepentingan kliennya. Ketentuan Pasal 5 UU No. 18 Tahun 2003 juga mengatur bahwa advokat berstatus sebagai penegak hukum, bebas dan mandiri yang dijamin oleh hukum dan peraturan perundang-undangan. Artinya advokat itu sebagai penegak hukum, maka ia harus memenuhi kode etik penegak hukum. Bebas dan mandiri artinya menunjukan indenpensi advokat yang bisa mendapat tekanan dari manapun. Advokat itu dapat saja menjadi mediator semua konflik.

Argumentasi kedua adalah bahwa tidak ada satu ketentuan pun dalam UU No. 18 Tahun 2003 yang melarang seorang advokat, untuk menjadi mediator harus juga memiliki sertifikat akreditasi sebagai mediator, ini hanya untuk menunjukkan kredibilitas mediator yang berkualiatas. Argumentasi ketiga adalah bahwa berdasarkan ketentuan Pasal 8 ayat (1) Peraturan Mahkamah Agung No. 01 Tahun 2008 Tentang Mediasi di Pengadilan mengatur bahwa para pihak berhak memilih mediator di antara adalah advokat. Penulis berpendapat selayaknya advokat dapat menjadi mediator dalam penyelesaian perselisihan hubungan industrial.

Kedua, dosen sebagai mediator. Ada beberapa argumentasi memungkinkan dosen sebagai mediator dalam penyelesaian perselisihan hubungan industrial. Argumentasi pertama, berdasrkan Pasal 1 ayat (2) UU No. 14 Tahun 2005 tentang Guru dan Dosen yang mengatur bahwa dosen adalah pendidik profesional dan ilmuwan dengan tugas utama mentransformasikan, mengembangkan menyebarluaskan ilmu pengetahuan, teknologi dan seni melalui pendidikan, penelitian, dan peng-abdian kepada masyarakat. Argumentasi kedua, ketentuan Pasal 72 UU No. 14 Tahun 2005 yang mengatur bahwa beban kerja dosen mencakup kegiatan pokok yaitu merencanakan pembelajaran, melaksanakan proses pembelajaran, melakukan evaluasi pembelajaran, membimbing dan melatih, melakukan penelitian, melakukan tugas tambahan, serta melakukan pengabdian kepada masyarakat”. Kewaji- ban pokok dosen adalah melaksanakan Tridarma Perguruan Tinggi, yaitu: pengajaran, penelitian dan pengabdian kepada masyarakat.

Argumentasi ketiga adalah bahwa dalam rangka kegiatan pengabdian masyarakat, di mana salah satu bentuk kegiatannya memberikan pelayanan hukum kepada masyarakat yaitu sebagai mediator sebagimana dijelaskan pada Keputusan Menteri Negara Koordinator Bidang Pengawasan Pembangunan dan Pendayagunaan Aparatur Negara No. 38/KEP/MK.WASPAN/8/ 1999 tentang Jabatan Fungsional Dosen Dan Angka Kredit. Ketentuan Pasal 4 mengatur bahwa salah satu kegiatan pengabdian kepada masyarakat yaitu memberi pelayanan kepada masyarakat atau kegiatan lain yang menunjang pelaksanaan tugas umum pemerintah dan pembangunan. Pada ketentuan semula ditentukan hanya PNS yang dapat menjadi mediator dalam penyelesaian perselisihan hubungan industrial, sebagai wujud pelaksanaan tugas umum pemerintah, maka dosen yang mempunyai kegiatan lain berupa pelaksanaan tugas umum pemerintahan juga dimungkinkan untuk menjadi mediator sebagai wujud pelaksanaan tugas umum pemerintahan di bidang ketenagakerjaan.

Ketiga, Komnas HAM sebagai mediator. Beberapa argumentasi yang memungkinkan Komnas HAM sebagai mediator dalam penyelesaian perselisihan hubungan industrial. Argumentasi pertama, ketentuan Pasal 75 UU No. 39 Tahun 1999 tentang Hak Asasi Manusia, adanya suatu lembaga Komnas HAM yang kegiatannya bertujuan: mengembangkan kondisi yang kondusif bagi pelaksanaan hak asasi manusia sesuai dengan Pancasila, Undang-undang Dasar 1945, dan Piagam Perserikatan Bangsa-Bangsa, serta Deklarasi Universal Hak Asasi Manusia; dan meningkatkan perlindungan dan penegakan hak asasi manusia, guna berkembangnya pribadi manusia Indonesia seutuhnya, dan kemampuannya dalam berbagai bidang kehidupan.

Argumentasi kedua, ketentuan Pasal 76 ayat (1) yang mengatur bahwa untuk mencapai tujuannya, Komnas HAM melaksanakan fungsi pengkajian, penelitian, penyuluhan, pemantauan dan mediasi tentang hak asasi manusia. Komnas HAM beranggotakan tokoh masyarakat yang 
professional, berdedikasi dan berintegrasi tinggi, menghayati cita-cita negara hukum dan negara kesejahteraan yang berintikan keadilan, menghormati hak asasi manusia dan kewajiban dasar manusia juga bisa menjadi mediator sebagaimana diatur pada Pasal 76 UU No. 39 Tahun 1999. Dalam praktiknya di masya-rakat banyak ditemukan kasus pelanggaran HAM yang dilakukan pengusaha, seperti pekerja tidak diberi hak libur melakukan ibadah keagamaan, cuti tahunan dengan alasan pekerja pada tahun yang sama telah menikmati cuti melahirkan ini terdapat pada kasus nomor: 17/G/2010/PHI.Jbi, di kota Jambi.

Advokat, dosen, Komnas HAM dan profesi lain yang dianggap para pihak menguasai atau berpengalaman dalam pokok sengketa juga patut dipertimbangkan untuk dapat menjadi mediator. Hal ini didasarkan pada pertimbangan sebagai berikut. Pertama, ditunjuknya seorang mediator dalam penyelesaian perselisihan hubungan industrial pada pokoknya ditentukan oleh dua faktor yaitu: kesepakatan para pihak yang terlibat perselisihan untuk menunjuk seseorang dan orang tersebut memiliki kemampuan dan pengetahuan terhadap persoalan yang mereka tengah hadapi, maka dengan demikian sangat dimungkinkan seseorang yang bukan berprofesi sebagai akademisi atau praktisi hukum namun ia menguasai dan berpengalaman dalam penyelesaian perselisihan hubungan industrial dijadikan sebagai mediator. Misalnya pensiunan pegawai negeri sipil di instansi pemerintah yang bertanggung jawab dibidang ketenagakerjaan, di mana ia tidak berprofesi sebagai advokat ataupun dosen, tetapi integritas, penguasaan akan pokok perkara, pengalaman dan obyektivitasnya telah teruji dibidang penyelesaian perselisihan hubungan industrial oleh berbagai pihak, termasuk para pihak yang tengah berselisih. Kedua, sebagaimana halnya seorang advokat, Profesi bukan hukum yang dianggap para pihak menguasai atau berpengalaman dalam pokok sengketa juga di akui keberadaannya menurut Pasal 8 ayat (1) Peraturan Mahkamah Agung No. 01 Tahun 2008.

Langkah selanjutnya, setelah ditentukan pihak-pihak mana saja yang dapat menjadi me- diator, adalah diadakan perbaikan atau revisi terhadap ketentuan UU No. 2 Tahun 2004 dan peraturan pelaksananya. Bentuk perbaikan/revisi tersebut adalah sebagai berikut. Pertama, mediator dalam konsep ketentuan Pasal 1 ayat (12) UU No. 2 Tahun 2004 direvisi menjadi konsep: "Mediator Hubungan Industrial selanjutnya disebut mediator adalah pegawai instansi pemerintah di bidang ketenagakerjaan yang memenuhi syarat atau pihak ketiga yang netral yang ditunjuk oleh para pihak berdasarkan perjanjian dan mampu menyelesaikan perselisihan hubungan industrial untuk menghasilkan anjuran". Dalam konteks ini, peneliti berharap adanya perluasan pada jenis lembaga yang dapat menjadi mediator. Perluasan kesempatan bagi lembaga atau institusi lain menjadi mediator adalah sebagai penerapan dari asas kesamaan kedudukan dalam hukum bagi lembaga peradilan untuk menyelesaikan perselisihan dan penerapan asas kebebasan bagi para pihak yang berselisih untuk memilih lembaga peradilan yang mereka percayai netral dan mampu menyelesaikan perselisihan. Kedua, ketentuan Pasal 8 UU No. 2 Tahun 2004 perlu direvisi menjadi "Penyelesaian perselisihan hubungan industrial melalui mediasi dapat dilakukan oleh mediator dari pegawai negeri sipil di bidang ketenagakerjaan yang dilegitimasi oleh Menteri atau mediator yang dipilih oleh pihak yang berselisih berdasarkan perjanjian tertulis."

Perubahan rumusan kedua pasal tersebut diharapkan akan tercipta pengaturan mediasi yang ideal untuk penyelesaian perselisihan hubungan industrial yang adil dan objektif. Perluasan jenis lembaga yang dapat menjadi mediator tidak akan lengkap jika tidak diikuti perubahan aspek prosedur mediasi.

Prosedur mediasi dalam UU No. 2 tahun 2004 yang perlu direvisi dalam rangka reformasi hukum

Prosedur mediasi sebagaimana yang diatur dalam UU No. 2 Tahun 2004 dan peraturan pelaksana pada dasarnya dapat diterapkan untuk prosedur mediasi pada mediator tipe independent. Mengutip pendapat Galenter bahwa kehadiran pengadilan alternatif tidak perlu ter- 
jadi dalam bentuk fisik, tetapi (juga) dalam proses-proses yang berlansung. ${ }^{16} \mathrm{Hal}$ ini berarti, bahwa jika para pihak menyepakati selain yang ditentukan oleh peraturan perundang-undangan, asalkan tidak bertentangan dengan peraturan perundang-undangan, maka prosedur dapat diserahkan saja kepada mediator (selain PNS Disnaker) tentu saja dengan kesepakatan para pihak. Penyelesaian perselisihan secara mediasi meskipun dibantu oleh mediator, namun mediator tetap memakai prinsip musyawarah untuk mufakat.

Musyawarah untuk mufakat merupakan prinsip yang dipakai dalam menyelesaikan perselisihan diluar pengadilan. Beberapa hal yang perlu diperhatikan para pihak sebagai pedoman yaitu: adanya perjanjian tertulis dari para pihak, yang disebut perjanjian mediasi, materi minimum yang harus diatur dalam perjanjian ini antara lain meliputi: identitas para pihak yang berselisih, tempat mediasi yang dipilih, nama mediator yang dipilih, honorarium dan biaya perjalanan mediator, penyelesaian memprioritaskan prinsip musyawarah untuk mufakat, para pihak berhak menerima atau menolak anjuran dari mediator, batasan jangka waktu penyelesaian, dapat ditentukan sesuai kesepakatan, namun idealnya tidak melebih batas waktu 30 (tiga puluh) hari sebagaimana yang diatur dalam UU No. 2 Tahun 2004, kesepakatan untuk melaksanakan hasil musyawarah antara mediator dengan para pihak yang berselisih dan apabila kesepakatan tidak tercapai para pihak dapat mengajukan penyelesaian, perselisihan ke pengadilan hubungan industrial sesuai peraturan yang berlaku, dengan disertai risalah telah pernah diupayakan penyelesaian secara mediasi.

\section{Penutup \\ Simpulan}

Pengaturan penyelesaian perselisihan hubungan industrial secara mediasi dalam perspektif UU No. 2 Tahun 2004, dapat diuraikan dari beberapa aspek, yaitu kelembagaan, dan

16 Galenter dalam Satjipto Raharjo, "Melihat Kembali Peran Mahkamah Agung", Jurnal Hukum Pantarei, Vol. 1 No. 3, Februari 2009, Jakarta: Konsorsium Reformasi Hukum Nasional, hlm.13. prosedur penyelesaian. Aspek kelembagaan menunjukan bahwa secara kelembagaan yang berwenang menyelesaikan perselisihan hubungan industrial melalui mediasi hanya mediator yang berasal dari pegawai negeri sipil di instansi pemerintah yang bertanggung jawab dibidang ketenagakerjaan. Aspek prosedur penyelesaian yaitu dalam waktu selambat-lambatnya 7 (tujuh) hari kerja setelah menerima pelimpahan penyelesaian perselisihan mediator harus sudah mengadakan penelitian tentang duduknya perkara dan segera mengadakan sidang mediasi dan penyelesaian melalui mediasi dilaksanakan paling lama 30 (tiga puluh) hari kerja terhitung sejak menerima pelimpahan penyelesaian perselisihan

Konsep pengaturan mediasi yang ideal untuk menyelesaikan perselisihan hubungan industrial dengan adil dan objektif. Mediator,secara kelembagaan, dapat juga dari pihak ketiga yang independent, seperti advokat, akademisi atau dosen, Komnas HAM, atau pihak ketiga lain yang mampu menyelesaikan perselisihan hubunngan industrial.

Aspek prosedur mediasi perlu diadakan reformasi yakni prosedur mediasi sebagaimana yang diatur dalam UU No. 2 Tahun 2004 dan peraturan pelaksana pada dasarnya dapat diterapkan untuk prosedur mediasi pada mediator tipe Independent. Para pihak, jika menyepakati selain yang ditentukan oleh peraturan perundang-undangan, asalkan tidak bertentangan dengan peraturan perundang-undangan maka prosedur dapat diserahkan saja kepada mediatornya tentu saja dengan kesepakatan para pihak.

\section{Saran}

Pembentuk undang-undang segera merevisi UU No. 2 Tahun 2004 khususnya berkenaan dengan aspek mediasi. Hal ini dimaksudkan untuk dapat memenuhi tuntutan dan kebutuhan hukum masyarakat.

\section{Daftar Pustaka}

Adi, Mila Karmila. "Masa Depan Arbitrase Sebagai Mekanisme Penyelesaian Perselisihan Hubungan Industrial di Indonesia”. Jurnal 
Hukum FULTEX. Vol. 17 No. 2. April 2010. Yogyakarta: FH UII;

Dahlia dan Agatha Jumiati. "Penyelesaian Perselisihan Hubungan Industrial Berdasarkan Undang-undang Nomor 2 Tahun 2004". Jurnal Wacana Hukum. Vol. IX No. 2. Oktober Tahun 2011. Surakarta: Fakultas Hukum Unisri;

Fitriyani, Riska. Proses Mediasi di Kabupaten Siak. Jurnal Ilmu Hukum. Vol. 3 No.1. Tahun 2013. Pekanbaru: FH Universitas Riau;

Kunarti, Siti. "Perjanjian Pemborongan Pekerjaan (Outsorcing) dalam Hukum Ketenagakerjaan". Jurnal Dinamika Hukum. Vol.9 No. 1. Januari 2009. Purwokerto: FH Unsoed;

Margono, Suyud. 2004. Alternative Dispute Resolution dan Arbitrase. Proses Pelembagaan dan Aspek Hukum. Bogor: Ghalia Indonesia;

Muhammad, Rusli. "Kemadirian Pengadilan Dalam Proses Pebegakan Hukum Pidana Menuju Sistem Peradilan Yang Bebas Dan Bertanggung Jawab". Jurnal Hukum. Vol. 16 No. 4. Oktober 2009. Yogyakarta: FH UII Yogyakarta;

Prayitno, Kuat Puji. Restorative Justice Untuk Peradilan Di Indonesia (Perspektif Yuridis Filosofis Dalam Penegakan Hukum In Concreto). Jurnal Dinamika Hukum. Vol. 12 No. 3. September 2012. Purwokerto: FH Unsoed;

Putong, Diana. 2012. "Penyelesaian Perselisihan Tenaga Kerja Kasus Adam Air Melalui Mediasi Pada Tahap Perundingan Tripartit Berdasarkan Undang-udang No.2 Tahun 2004". Jurnal Arika. Vol. 06. No. 1. Februari 2012;

Raharjo, Satjipto. "Melihat Kembali Peran Mahkamah Agung". Jurnal Hukum Pantarei.
Vol. 1 No. 3. Februari 2009. Jakarta: Konsorsium Reformasi Hukum Nasional;

Ramli, Lanny. Ratio Legis PNS Sebagai Mediator Dalam Penyelesaian Perselisihan Hubungan Industrial. Jurnal Magister Hukum Vol. 1 No. 2 Tahun 2010. Universitas Wisnuwardhana Malang. tersedia dalam website http://isjd.pdii.lipi.go.id/admin/jurnal/1 210296338_2086_6526.pdf;

Ratio PNS Sebagai Mediator dalam Penyelesaian Perselisihan Hubungan Industrial. Jurnal Magister Hukum. Vol. 1 No. 2. Tahun 2010. Malang: Program Studi Magister Ilmu Hukum Universitas Wisnuwardhana. Tersedia di website isjd.pdii.lipi. go.id/admin/jurnal/1210296338_2086_65 26.pdf;

Sinaga, Frendy. "Tinjauan Yuridis Terhadap Anjuran Yang Dikeluarkan Mediator Hubungan Industrial Di Dinas Tenaga Kerja Dan Transmigrasi Provinsi Kalimantan Timur". Jurnal Beraja Niti. Vol. 2 No. 12 Tahun 2013. Fakultas Hukum Universitas Mulawarman. Tersedia di website http:// ejournal.fhunmul.ac.id/index.php/bera$\mathrm{ja} /$ article/view/142 diakses 12-2-2014;

Supriyanto, Bambang Heri. "Mediasi Sebagai Salah Satu Penyelesaian Senketa Bisnis Di Pusat Mediasi Nasional". Jurnal Reformasi Hukum. Vol. XIV No.1 Januari-Juni 2010. Jakarta: Universitas Islam Jakarta;

Wijayanti, Asri. "Reformasi Hukum Dalam Penyelenggaraan Jamsostek Bagi Pekerja Swasta". Yustitia. Vol. 1 No. 1. April 2007. Surabaya: UM Surabaya. diakses melalui http://apps.um.surabaya.ac.id/ gdl.php?mod=browse\&op=read\&id=umsura baya-1912-asriwijayanti-30;

2009. Hukum Ketenagakerjaan Pasca Reformasi. Jakarta: Sinar Grafika. 